OPEN ACCESS

Edited by:

Eileen Scanlon,

The Open University, United Kingdom

Reviewed by:

Jon Mason,

Charles Darwin University, Australia Canan Blake,

University College London, United Kingdom

*Correspondence: Justin D. Shanks

justin.shanks@montana.edu

Specialty section: This article was submitted to

Digital Learning Innovations,

a section of the journal

Frontiers in Education

Received: 17 April 2020

Accepted: 18 August 2020

Published: 11 September 2020

Citation:

Shanks JD (2020) Toward A Contemplative Technopedagogy Framework: A Discourse Analysis. Front. Educ. 5:553212. doi: 10.3389/feduc.2020.553212

\section{Toward A Contemplative Technopedagogy Framework: A Discourse Analysis}

\author{
Justin D. Shanks* \\ ${ }^{1}$ Library, Montana State University, Bozeman, MT, United States
}

Digital technology features prominently in the higher education ecosystem, affecting the ways in which educators think, communicate, and teach. This research applies discourse analysis to articles published within The Chronicle of Higher Education (CHE) to understand: (1) The ways in which conceptions of digital technology in higher education pedagogy have changed and the ways in which they have remained consistent from 1993 to 2016 and (2) The extent to which CHE articles addressed attributes of contemplation with regard to technopedagogy. Research findings indicate that during the previous 23 years digital technology was portrayed as an overwhelmingly positive addition to higher education pedagogy. Less than half of articles analyzed contained attributes of contemplation. Non-contemplative technopedagogical approaches can lead to uncritical adoption or knee-jerk dismissal of digital technology - either of which can have substantial and long-lasting consequences within teaching-learning environments. Contemporary pedagogies need to pay closer attention to digital technologies, but must do so in a purposeful and engaged manner. This historical and discursive research inductively led to the development of the Contemplative Technopedagogy Framework, which provides an approachable introduction to using attributes of contemplation when making pedagogical decisions about digital technology in higher education.

Keywords: pedagogy, technology, contemplation, mindfulness, The Chronicle of Higher Education

\section{INTRODUCTION}

From the personal computers in the 1980s to contemporary cloud computing, digital technology is an ever-present feature of higher education. Given the omnipresence of digital technology throughout the higher education landscape, there exists a deeply ingrained and widespread assumption that digital technology not only will be, but in fact should be used for purposes of teaching.

Course management systems (CMS) are championed for enabling instructors to easily and efficiently distribute course information and content to students via the Internet (Harrington et al., 2004). Common CMS platforms include Canvas, Desire2Learn, Google Classroom, Moodle, and Sakai. CMS provide collections of software and online tools for course interactions are also referred to as learning management systems (LMS) or virtual learning environments (VLE). Over $90 \%$ of universities and colleges in the United States and United Kingdom utilize CMS (Browne et al., 2006; Hawkins and Rudy, 2007). 
Walking into nearly any classroom on an American college campus, observers are likely to see students and faculty reading from and typing upon various models of laptop computers. During the 2015-2016 academic year, 95\% of students owned a laptop and used it for coursework (Brooks, 2016). The prevalence of CMS and laptops are two brief examples that illustrate how digital technology has become ingrained within the infrastructure and daily practice of higher education.

While CMS and laptops are relatively recent technologies, the evolving nature of technology is not a new conversation in the history of higher education. Education has a longstanding relationship with various technologies from paper and chalkboards to televisions and laptops (Kidwell et al., 2008). The integration of technology in effort to mechanize, automate, or otherwise improve education has been a topic of inquiry since the Ancient World (Buck, 1989). Technology and its role in higher education is routinely reimagined (Office of Educational Technology, 2017). Since the late 20th century, the predominant focus of the voluminous research regarding the roles of technology in higher education has been on digital technology. For example, along with the Internet came bold predictions that online environments and software applications would transform teaching practices across higher education (Blin and Munro, 2008, p. 475). Various streams of pedagogical research have addressed the complexities of decision-making involving digital technology use in higher education teachinglearning environments (Burgess et al., 2010; Anderson and Dron, 2011; Koehler et al., 2013).

The constantly changing nature of technology in higher education lends itself to another conversation focused on thinking critically about the whys and hows of pedagogy with technology. Due in part to the recognized benefits it brings to teaching and learning, the practice of contemplative pedagogy in higher education has increased in recent years (Levy, 2006). Since the late twentieth century, terminology such as contemplative (Gunnlaugson et al., 2014), thoughtful (Privateer, 1999), design (Reeves et al., 2005), mindful (Varlotta, 2017), and critical (Miller, 2017) appear sporadically throughout higher education literature and convey the importance of contextual considerations in regard to pedagogical considerations uniquely associated with the integration of digital technology, otherwise known as technopedagogy (Newson, 1999).

Literature focused on contemplative practices in higher education warns about the uncritical adoption of technology without regarding the whys and hows of its pedagogical application (Hargittai, 2010). Much of the literature discusses contemplative practices with respect to student learning (Hart, 2004; Fisher, 2017). Hart (2004) explains that introducing contemplation into the classroom can deepen a student's awareness, concentration, and creativity. There is decidedly less attention to matters of contemplative practices with regard to pedagogy. Buchmann (1989) stresses that "teacher thinking must be expanded beyond planning and decision making" to also include processes of contemplation. Even less literature addresses the role of contemplative practices with regard to technopedagogy in higher education. Levy (2007) discusses how the contemplative practice of "slow-time" can enhance learning, teaching, and research by countering "fast-time," which he sees as directly related to ever-present digital technology.

More than simply a situation where new technologies usher in new pedagogies, the changing technosocial educational environment demands that educators think contemplatively about technologies and pedagogies. Digital technologies are not only transforming what it means to be a student, but also what it means to be a teacher.

Practices of teaching in higher education are influenced by discourses about and ideologies regarding digital technology. Developing a new approach to teaching within contemporary higher education requires understanding discourse regarding the promise, potential, and peril of digital technology. Moreover, it is important to know the extent to which this discourse incorporates attributes of contemplation. This manuscript will encourage reflective dialogue to engender more deliberate approaches to digital technologies via contemplative consideration of technopedagogy.

Among the most prominent spaces where the larger conversation about digital technology and pedagogy in higher education takes place is within the pages of The Chronicle of Higher Education (CHE). Based in Washington, DC, CHE is the "No. 1 source of news, information, and jobs for college and university faculty members and administrators" (About The Chronicle of Higher Education, 2017). This electronic database was selected because it is frequently accessed by higher education professionals, with 12.8 million pageviews and 1.9 million unique visitors a month, and technology and pedagogy are significant themes in its publications. Originally started in 1966 as a print newspaper, CHE integrated an online newspaper in 1993. CHE is now offered both in print format (published weekly during the academic year and less so from May until August and December) and in digital format (published each weekday). As a non-disciplinary, broadly comprehensive publication addressing higher education news, information, and concerns, CHE provides an exemplary research site for understanding conceptions of digital technology and integration of contemplation for pedagogy in contemporary higher education. During the previous three decades, CHE articles have excitedly introduced new technologies, skeptically bemoaned changing ideologies, and shared various best practices. $\mathrm{CHE}$ articles are written by and for everyday academics - those pedagogical practitioners who are routinely faced with decisions about when, which, why, how, and to what extent to use digital technology in their teaching.

In analyzing $\mathrm{CHE}$ articles, this manuscript answers two questions: (1) In what ways have conceptions of digital technology in higher education pedagogy changed and in what ways have they remained consistent from 1993 to 2016? and (2) To what extent do CHE articles address attributes of contemplation with regard to technopedagogy? This two-fold inquiry is important to execute in tandem - a new framework for teaching with digital technology should build upon an understanding of the preceding discourse. These questions are answered through a discourse analysis of a representative and randomized set of $\mathrm{CHE}$ articles. Research findings provide an understanding of the conversation about technology and 
pedagogy in higher education and help to guide the next phase of this conversation toward a more contemplative approach to discussing, evaluating, and utilizing digital technology in United States higher education. Ultimately, this manuscript outlines a framework that will aid everyday academics in making contemplative decisions about when, which, to what extent, how, and for what purpose to integrate digital technology into the teaching-learning environment.

\section{CONCEPTUAL FRAMEWORK}

This manuscript investigates the portrayal of technology, pedagogy, and contemplation using an interdisciplinary science and technology studies (STS) lens. STS is a discipline that integrates historical, sociological, and philosophical methods to better understand the interdependent relationship between science, technology, and society (Sismondo, 2007; Bijker et al., 2012; Felt et al., 2016). More specifically, this analysis of CHE is informed by theories and thinkers from history of technology, social construction of technology (SCOT), higher education studies, pedagogy, and contemplation. This manuscript draws upon methodological tools of discourse analysis developed within STS and the intellectual history of technology, in order to analyze what CHE authors mean when they write about technology in higher education (Coeckelbergh, 2017). STS provides a critical, self-reflexive form of discourse analysis trained upon social construction of technoscientific phenomena.

Discourse influences conception and conception subsequently influences action (Woolgar, 1986; Foucault, 2002). Conceptions about the roles expected of digital technology influence the purpose and practice of higher education pedagogy. Examining how digital technology is thought to augment higher education pedagogy illuminates the shifting conception of augmentation as well as that of pedagogy (Engelbart, 1962; Campbell, 2006). Conceptions define the parameters of what people think can or should happen with respect to digital technology and pedagogy in higher education.

Contemplation in and of itself is a conception that can find its way into the conversation regarding the purpose and practice of higher education technopedagogy. By either its absence or presence, the conception of contemplation influences technopedagogical actions. Worst case scenario, in the absence of contemplation, educators make uncritical decisions about pedagogy with digital technology. Best case scenario, contemplation is a key component of the decision-making process regarding the purpose and practice of higher education technopedagogy. While such conceptions can and do arise from multiple sources, textual publications are key sources for the dissemination of conceptions regarding digital technology and integration of contemplation in higher education pedagogy.

\section{KEY TERMS}

The analysis and subsequent argument set forth in this manuscript rely upon a shared understanding of the coming together of three key terms.

\section{Technology}

As Hughes (2005, p. 1) explains, "Technology is messy and complex. It is difficult to define and to understand... it is full of contradictions... and rich with unintended consequences." Used to refer to household appliances as well as ethereal software applications, technology is a term with a "tricky history” (Oldenziel, 2006). Moreover, technology is infused with power dynamics (Williams, 1985), sociocultural context (Marx, 1997; Williams, 2002), politics (Winner, 1977), among other variables that shape and are shaped by the conceptualizations of human actors (Schatzberg, 2006). More than merely the mechanistic, not exclusively the domain of engineering, nor purely about progress, this manuscript understands technology as one aspect of a complex sociocultural ecosystem. More specifically, this manuscript is interested in the subcategory of digital technology. This is not an effort to place the digital in opposition to the material. Indeed, the functional capability of digital technology requires the operation of physical hardware within the material world. In this manuscript, digital technology refers to the full gamut of electronic, data-oriented tangible objects and intangible networks (e.g., desktop computers, Internet, laptops, audiovisual recording software, tablets, social networking services, etc.).

\section{Pedagogy}

Broadly understood, pedagogy is the theory of education and practice of teaching (Lusted, 1986). The ways in which teachers teach are classified into and informed by pedagogical theories and strategies. This manuscript is interested in technopedagogy, which critically engages with pedagogical considerations uniquely associated with the integration of digital technology (Newson, 1999). The integration of digital technology into pedagogy should cause stakeholders in higher education to contemplate decisions about when, which, to what extent, how, with whom, and for what purpose to integrate digital technology into the teachinglearning environment (Newson, 1999; Cook-Sather, 2001; Boisselle et al., 2004).

\section{Contemplation}

Contemplation involves thinking carefully, deeply, and attentively about a topic. This approach to "thinking well" (Buchmann, 1989) covers a range of activities, from selfreflection to immersive concentration. As Levy (2006) reminds us, higher education has strong contemplative roots and "scholarship at its best involves focused, sustained, and receptive inquiry that is undeniably contemplative." While research about contemplation in education has seen a resurgence during recent years, historian Stock (2006) suggested that contemplation has deep roots in education that reach back to Ancient Greece. Philosopher and contemplative education scholar, Morgan (2015) similarly concluded that contemplation has a longstanding, but not always visible presence in education. For the purposes of this manuscript, contemplation refers to practices of purposeful and engaged thought. 


\section{Contemplative Technopedagogy (or Digital Technology and Contemplative Pedagogy)}

The integration of contemplation into pedagogy takes many forms and diverse meanings. Contemplative pedagogy emphasizes the value of incorporating meditation and other mindfulness exercises in coursework to enhance student attention and learning, and is sometimes wrapped into spirituality (Shapiro et al., 2008; Zajonc, 2013). Other educators have incorporated contemplation into curriculum through activities that provoke reflection, compassion, commitment, non-judgment, and creativity (Zajonc, 2006; Burggraf and Grossenbacher, 2007).

While it is important for scholars to engage in contemplative research and for students to have time and guidance for contemplative inquiry, higher education must also concern itself with the ways in which contemplation can inform technopedagogy. However, little research has been conducted to frame technopedagogy with contemplation.

\section{METHODS}

This manuscript investigates how the conceptions about technology and pedagogy have been imparted upon higher education professionals through articles published in CHE. Articles were selected for this literature review systematically from CHE, based upon methods suggested by Booth et al. (2012). An extensive mock keyword search was first conducted to determine the list of words that would yield the most comprehensive and relevant articles related to the research questions. Initial keywords included: CMS, computer, digital, education, instruction, learn, learner, LMS, pedagogy, teach, teacher, techno, technology (Figure 1).

The specific keywords were chosen because of their frequency of use in popular press and higher education discourse. Each keyword was entered into a separate search and the author reviewed titles and abstracts of 250 articles from the search results return for each keyword. Some search terms yielded almost synonymous articles. For example, searching for keyword "teach" returned results nearly identical to the search for keyword "technology." Other search terms were too general and did not yield useful results. For example, searching for keyword "education" returned nearly every article contained in the CHE database because the search term is contained in the publication's name. Ultimately, keywords that yielded articles most relevant to the research questions were selected. Subsequently, keywords were combined to further fine-tune the articles yielded by search results: "teaching" + "technology," "digital" + "technology," "pedagogy" + "technology" (Figure 2).

The search string "teaching" + "technology" was selected as most appropriate to answer research questions. Database search results indicated that search strings "digital" + "technology" and "pedagogy" + "technology" were duplicative of results obtained from the combined search terms "teaching" + "technology." The search string "technology" + "teaching" yielded the largest quantity of articles $(8,436)$ that were relevant to the research questions.

Articles were collected from 1993 to 2016. The earlier date was selected because it denotes a major shift in access to articles when CHE integrated an online format in 1993. The latter date was selected as the upper bound in order to capture the most recent full year of articles. Initially, all 8,436 titles and article abstracts were reviewed to determine if they focused upon technology and pedagogy in United States higher education. Articles with titles or abstracts that focused on non-United States higher education institutions, student learning outcomes, administration, finance and budget, research, technology with no mention of pedagogical application, pedagogy outside of higher education, or published in a non-text (audio or video) format were excluded. After the preliminary inclusion and exclusion, a database of 1,345 URLs was generated and sorted by year.

To analyze what CHE authors mean when they write about technology in higher education, this manuscript draws primarily upon the methodological framework of discourse analysis developed within STS (Coeckelbergh, 2017, pp. 88-89). STS provides a critical, self-reflexive form of discourse analysis trained upon the social construction of technoscientific phenomena.

Thematic and content analysis methods were used to understand how CHE articles portray technology and pedagogy as well as the integration of contemplative attributes. The author used thematic analysis to inductively develop themes in a systematic way (Guest et al., 2012). Thematic analysis was used to generate data inductively to elucidate conclusions from the data itself, rather than a deductive approach, which applies a theory or hypothesis to the data to draw specific conclusions. Content analysis was used to systematically quantify words within an established theme and analyze the distribution, frequency, and direction of words (Lasswell et al., 1952; Weber, 1990; Krippendorf, 2012). Kline's (2006) research regarding the emergence of "information technology" as a keyword, provided an additional model of STS-specific content analysis. Together, these methods make it possible to identify how the conversation about technology, pedagogy, and contemplation in higher education has or has not changed over the past few decades.

To gain an understanding of the potentially emerging themes about technology, pedagogy, and contemplation in higher education, the full text of each article $(n=1,345)$ was read and field notes produced. Based upon methods suggested by Neuendorf (2016) for digital media research, 10\% of articles per year $(n=137)$ were randomly selected for full content and thematic analysis from each year, 1993 through 2016.

Content and thematic analysis generally occurs until data saturation is reached; saturation occurred once the 137 articles were analyzed. The randomly selected articles were read, open coded, and data were extracted into the codebook. For each article, the codebook identified URL, year, date, author, title, purpose or summary, technologies identified, best practices for teaching, and sample quotes for specific themes and respective sub themes (described in "Results" and "Discussion" sections). Themes and sub themes were used to systematically generate categories that describe the discussion around technology, 

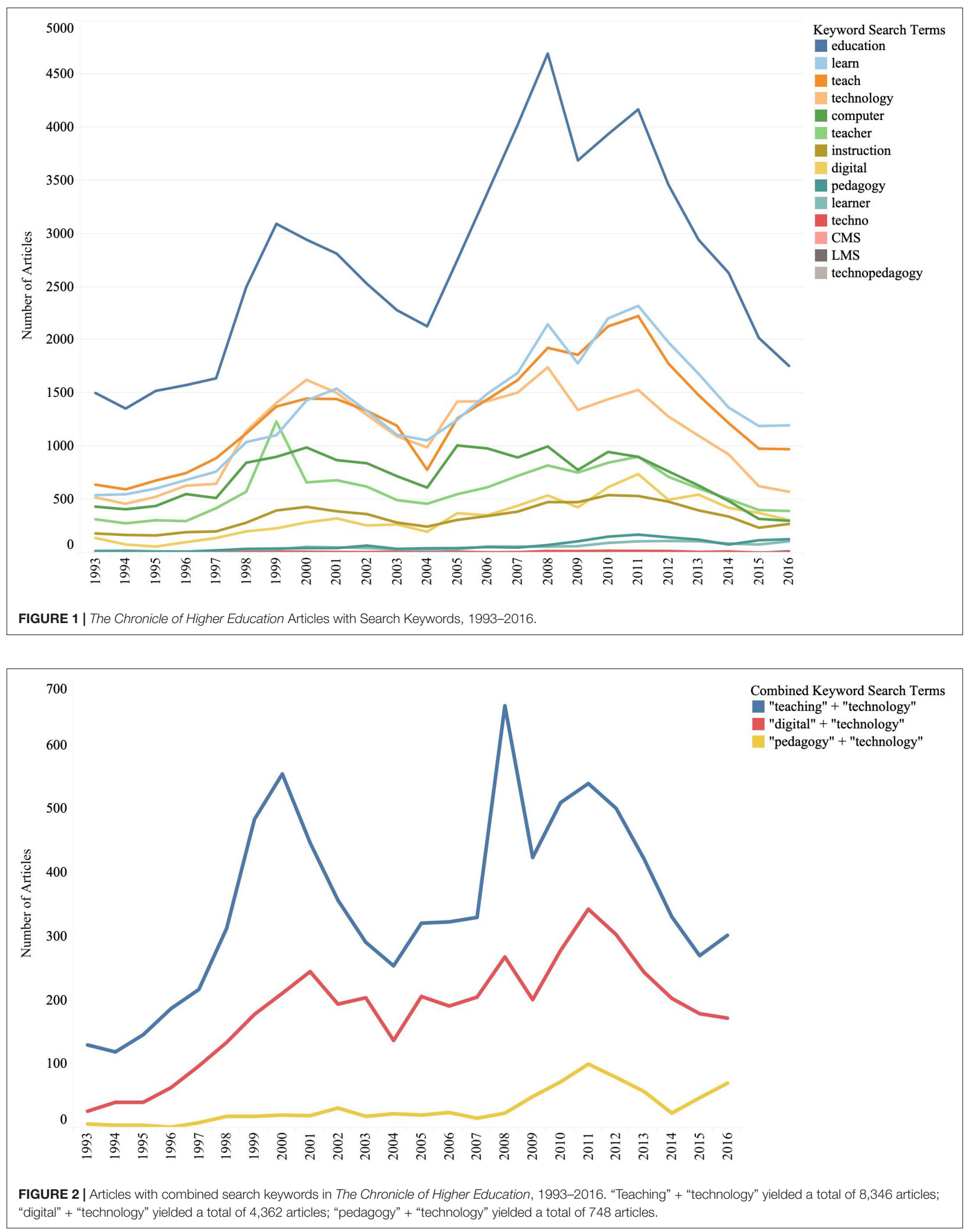
pedagogy, and attributes of contemplation in higher education as it exists in CHE from 1993 to 2016.

\section{RESULTS}

A total of 137 articles written by 78 unique authors (with 60 authors contributing only a single article) from 1993 to 2016 were analyzed via in-depth content analysis. On average, 5.7 articles per year were analyzed, with a range of 1-14 articles per year. Technologies discussed in the articles included personal computing devices, social media, online learning, world wide web, email, video conferencing, e-portfolios, and mobile technology. The specific technologies discussed in the 137 articles varied depending upon year, availability, and popularity. Nevertheless, there was a consistent pedagogical and technological discourse across the articles and throughout the years. The purposes of the articles ranged from technology reviews, best practices, and lessons learned to contemplation about technology use in a specific classroom or across campus to the role of technology in education and society more broadly. Two recurring themes and 14 sub themes were generated from the research to describe conceptions regarding technology and pedagogy in higher education as well as if and how attributes of contemplation were integrated into discussions of technology and pedagogy. Theme 1 - Conception of Technology and Pedagogy.

The CHE article author's Conceptions of Technology and Pedagogy (Figure 3) were categorized into sub themes: Positive, Negative, Positive and Negative, or Neutral.

It is critical to understand how the promises and/or shortcomings of digital technology for teaching are conveyed in higher education. Overwhelmingly, CHE article authors had a positive conception of digital technology for teaching. The author(s) portrayed digital technology as an asset to higher education teaching-learning environments in 81 articles. Many of the Positive portrayals championed the ways in which digital technology was certain to improve instruction. "And the technology is improving instruction, officials of the two colleges say. 'It has dynamically changed the way that we teach and the way that students learn"' (Young, 1998). Nearly equal amounts of articles portrayed digital technology as Negative $(n=18)$, Positive and Negative $(n=19)$, or Neutral $(n=14)$. Articles that were overtly critical or outrightly dismissive, such as Pyenson's (2011) disappointment about the changing face

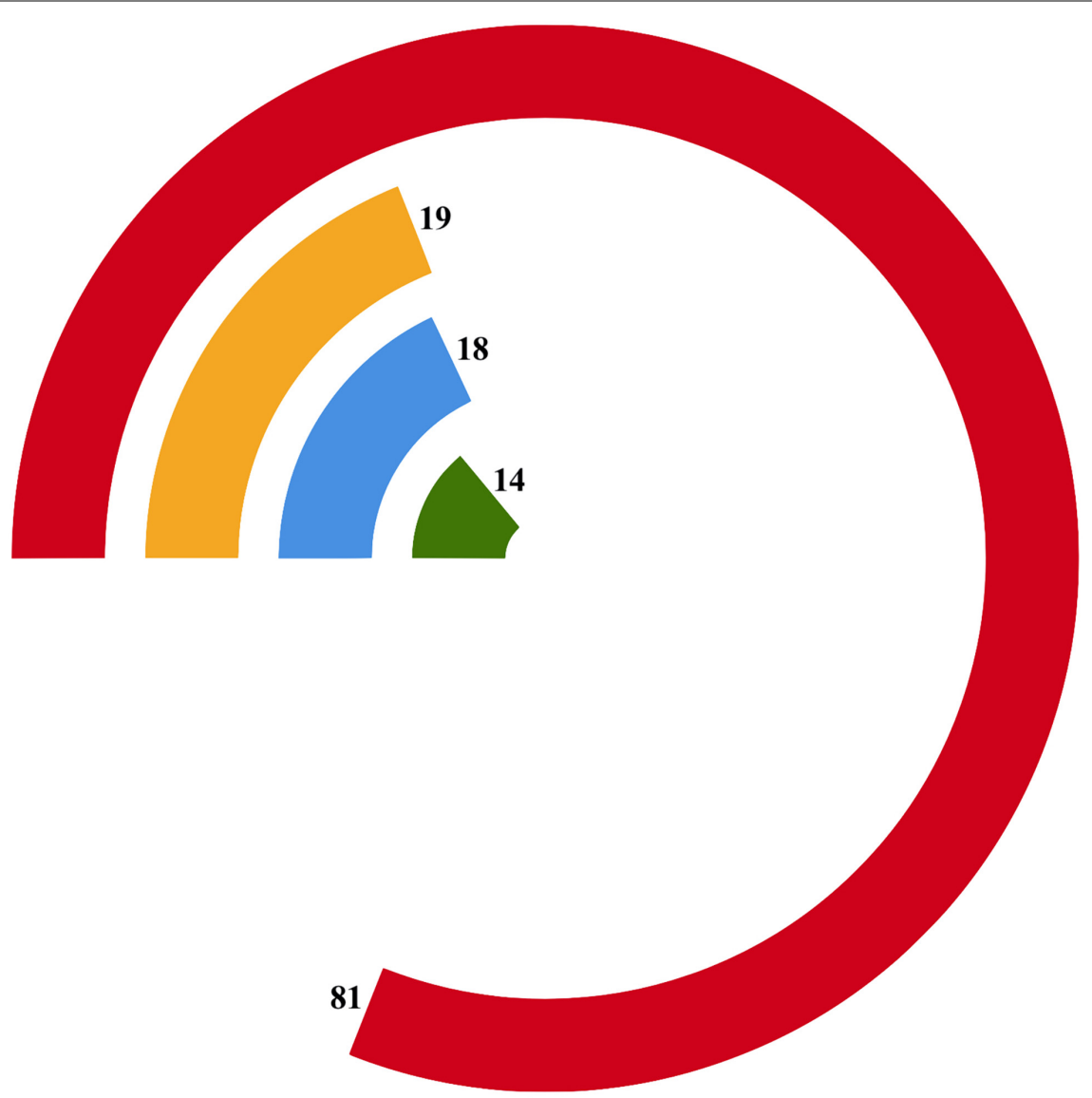

FIGURE 3 | Sub themes generated from discourse analysis of The Chronicle of Higher Education for conceptions of technology and pedagogy theme. Numbers in this figure indicate quantity of articles associated with each sub theme. 
of higher education, were categorized as Negative. "We are already well on the way to being enslaved by gadgets, and America's second- and third-tier institutions of higher learning are being reduced to the level of trade schools for producing technicians to fix those gadgets. Homo sapiens and Homo ludens have, in our time, been displaced by Homo faber." Articles featuring a more well-rounded critique of both the benefits and costs of digital technology were categorized as Positive and Negative. Maloney (2007) provides a fine example of this approach when discussing CMS. "The problem is not the idea of a course-management system itself...nor the various uses of such systems, many of which serve their purposes quite well. Rather, the problem is that most course-management systems were developed at a time when the Internet was seen primarily as a mechanism for information delivery. Course-management systems were not created to enhance learning, but to make it easier for a faculty member to deliver materials to students." Some articles focused entirely on communicating survey data or introducing new a digital technology without forecasting its utility or evaluating its effectiveness. Articles without a value statement about technology in higher education were categorized as Neutral.

\section{Theme 2 - Attributes of Contemplation in Pedagogy and Technology}

Attributes of Contemplation (Figure 4) were expressed via 9 sub themes: Teaching Mindfulness, Iterative Design, Pedagogy Focused Faculty Development, Being Present, Connecting, Functional Evaluation, Intentionality, Pedagogy First, Technosocial Dynamics, or No Attributes of Contemplation. Few articles explicitly mention contemplation or its various synonyms, nevertheless attributes of contemplation exist beneath the surface influencing conceptions of technology and guiding technopedagogical practice.

\section{No Attributes of Contemplation}

Approximately 64\% $(n=88)$ of articles analyzed contained no mention of attributes associated with contemplation. Articles in this category did not discuss technology purposefully or with engaged thought about pedagogical dynamics. Nearly half of all articles in this category were also categorized as portraying technology positively in Theme 1 .

\section{Pedagogy First}

One of the largest sub themes $(n=8)$ emphasized the importance of tailoring technology to suit pedagogy, rather than tailoring pedagogy to suit technology. Farman (2012) acknowledges the multitude of technology choices, but simultaneously illustrates how his pedagogy influences decisions about the use of any digital technology in the teaching-learning environment. "From my perspective, as an educator, I must respond those practices that have become pervasive in the lives of my students, demonstrate that there are many ways to use these tools, and, ultimately, show them how to analyze and critique their own everyday practices. I am taking small steps toward figuring out the best techniques to achieve those goals."

\section{Technosocial Dynamics}

The other large sub theme $(n=8)$ included articles that critically evaluated the relationship between technology and society, both within and beyond the classroom. Turkle (2004) captures this interdependent relationship between society, technology, and higher education in her assessment of the shaping power of information technology. "The tools we use to think change the ways in which we think. The invention of written language brought about a radical shift in how we process, organize, store, and transmit representations of the world. Although writing remains our primary information technology, today when we think about the impact of technology on our habits of mind, we think primarily of the computer."

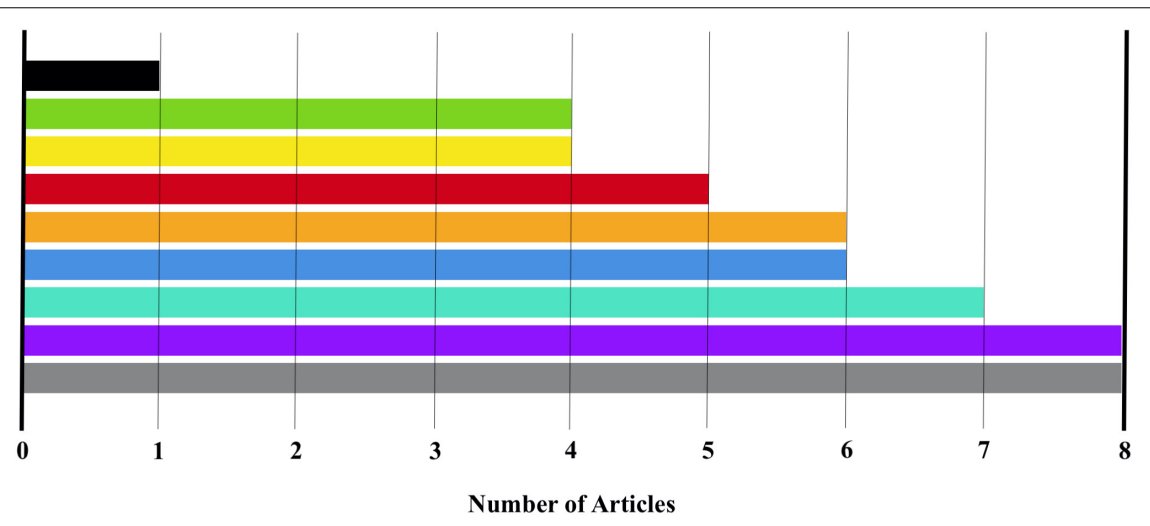

Teaching Mindfulness

Pedagogy Focused Faculty Development

Iterative Design
Being Present

Functional Evaluation

Connecting
Intentionality

Technosocial Dynamics

Pedagogy First

FIGURE 4 | Sub themes generated from discourse analysis of The Chronicle of Higher Education for attributes of contemplation in pedagogy and technology theme. The bar chart only includes articles that were coded as contemplative. An addition 88 articles were coded as not contemplative. 


\section{Intentionality}

Seven articles conveyed the importance of engaged and purposeful thinking when making decisions about the suitability of a technology for use in a teaching-learning environment. Faced with expanding class sizes, Sample (2011) purposefully sought out digital technology that would enable him to maintain a studentcentered environment in order to build an engaged learning community. "My classes are student-centered, hands-on, and discussion-oriented, and I rarely hold forth in any kind of lecture mode. Rather than looking at the shift from a smaller class to a supersized class as a hardship, I see it as a challenge: How do I continue to engage students on a dialogic and experiential plane when institutional momentum seems to curtail all but the most traditional forms of pedagogy?"

\section{Connecting}

Connecting $(n=6)$ was an attribute of contemplation focused on cultivating authentic relationships between members of the teaching-learning environment. These articles discussed the pros and cons of using digital technology as a technopedagogical strategy to develop a relationship between teacher and learner. "At its best, Mr. Wesch believes that interactive technology and other methods to create more active experiences in the classroom - can be used to forge that kind of relationship between teachers and students where professors nurture rather than talk down to students" (Young, 2012).

\section{Functional Evaluation}

Functional Evaluation $(n=6)$ occurred when an article assessed particular features of a specific technology with relationship to pedagogical aims. These quasi-case studies examined how a specific digital technology did or did not work well in a particular course. Wymer (2006) provides an in-depth analysis of her experience using instant messenger to communicate with students instead of email. "Consider, though, what it means to invade that technological space. Students use new technologies as a way to express themselves and their individuality. They develop identities related to those technologies, and those identities are not always the ones they would like to bring into the classroom."

\section{Being Present}

Avoiding the distractive potential of technology in the classroom in order to focus on the teaching-learning environment was the central tenet of Being Present $(n=5)$. A major theme running throughout contemplation research is the necessity of being present in the face of constant distraction. In response to banning digital technology in her classroom in hopes of enhancing inclass attentiveness, Mandell (2015) discusses the reaction from students, "Simply requesting that students put away their phones was an exercise in futility. Adding a line in the syllabus that there would be grade penalties for unprofessional use of technology brought about no change in their habits of swiping and clicking. They meant no disrespect."

\section{Iterative Design}

Iterative Design $(n=4)$ requires the educator to accept the iterative nature of teaching with technology. Acknowledging that the educator is constantly learning about technology and exploring how to potentially use it for teaching, Saltzer (2011) discussed the evolving nature of her gamification class website, "So with the summer almost upon us, I'll be taking my notes from this semester and working on crafting a more playful, collaborative iteration for the fall."

\section{Pedagogy Focused Faculty Development}

It is common for American universities to include programs or centers that teach faculty how to use digital technology for teaching. Four articles articulated a need for such centers to first cultivate pedagogical expertise before emphasizing the integration of digital technology into the teaching-learning environment. In an article that explores various courses for teachers to learn how to effectively teach online, an administrator for one course explains, "The ones who come in expecting that it will require little work have their eyes opened pretty quickly, 'he says.' We help them understand that it's a classroom, not a Web site" (Gose, 2010).

\section{Teaching Mindfulness}

A single article explained the benefits of mindful technology practices learned during a course titled, "Information and Contemplation" at University of Washington. "It began with an assignment that required students to spend $15 \mathrm{~min}$ to half an hour each day observing and logging their e-mail behavior. The idea, an outgrowth of meditation, is to note what happens in the mind and body" (Parry, 2013). In the face of device distraction and information abundance, there exists a need to sharpen focus and strengthen attention. In this course, the professor teaches students about meditation techniques in order to help still their minds and cultivate attentive focus.

\section{DISCUSSION}

Why is digital technology expected to revolutionize higher education? This mindset is symptomatic of the larger sociocultural assumption that digital technology will fix whatever needs repair, now and in perpetuity. CHE articles from 1993 to 2016 suggest a strong desire to change higher education. The revolutionary (or at least renovative) aims of $\mathrm{CHE}$ articles are echoed within higher education research (Green and Gilbert, 1995; Office of Educational Technology, 2017). Moreover, digital technology is seen as a primary means to achieve this end.

Technology in higher education is not problematic in and of itself. Rather, the issue lies with our sociocultural (mis)conception of technology's role within higher education. Basic problems associated with technology in higher education result from a lack of understanding about technology. Other problems are caused by limited scope and often prescriptive ways of approaching education. Problems associated with technology in higher education will not be solved by less technology or by more technology. Echoing McLuhan, Postman and Weingartner (1969, p. 204) suggest "that media study become an integral part of all your classes. No matter what 'subject' you are teaching, media 
are relevant." To realize the full gravity (with respect to digital technology in higher education) of Postman and Weingartner's mention of McLuhan, it is important to recall that McLuhan (1964) considered media as any and all technological extensions of human bodies and minds that control the shape and form of association and action. Problems do not reside within the technology, but our conceptions thereof.

An unexamined embrace of digital technology and associated pedagogical practice is a surefire recipe for disaster, or at least dissatisfaction. If digital technology is to positively augment higher education, it must involve contemplation. A contemplative technopedagogy has the potential to change what it means to be a teacher, which in turn can change what it means to be a learner. Digital technology is far more than information delivery. Digital technology can enable communication and creation. A contemplative technopedagogy creates an educational environment that builds connections and changes norms within and among communities of learning physical, digital, spatial, conceptual, etc. What follows is an introduction to the Contemplative Technopedagogy Framework (Figure 5) which aims to facilitate purposeful and engaged approaches to pedagogical practices involving digital technology in higher education.

\section{TOWARD A CONTEMPLATIVE TECHNOPEDAGOGY FRAMEWORK}

Some articles from $\mathrm{CHE}$ are attentive to the roles that attributes of contemplation can play when making pedagogical decisions about digital technology. More than half of $\mathrm{CHE}$ articles analyzed contain no attributes of contemplation. Non-contemplative technopedagogical approaches can lead to uncritical adoption or knee-jerk dismissal of digital technology - either of which can have substantial and long-lasting consequences within teaching-learning environments. Contemporary pedagogies need to pay closer attention to digital technologies, but must do so in a purposeful and engaged manner. This discussion does not posit a new theory of higher education pedagogy. Rather, it articulates ways in which educators can become more contemplative about their technopedagogy instead of immediately and uncritically adopting of dismissing digital technology. There is both need and opportunity to create a contemplative technopedagogy framework within higher education and this is a step in that direction.

Analysis of $\mathrm{CHE}$ articles determined that the portrayal of digital technology has not dramatically changed from 1993 to 2016. Portrayals are overwhelmingly positive. Evangelists remain

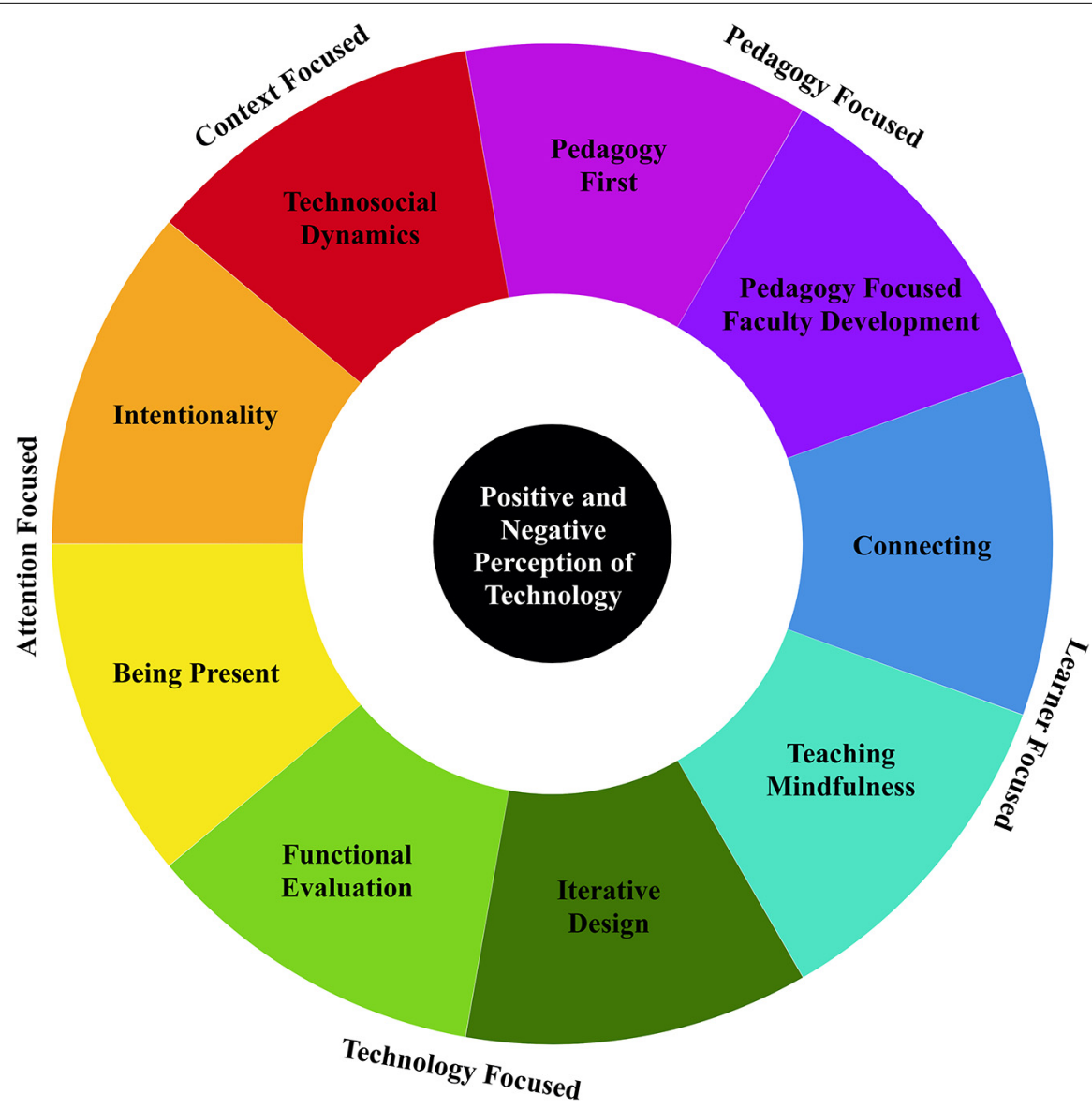

FIGURE 5 | Contemplative technopedagogy framework generated from discourse analysis of The Chronicle of Higher Education, $1993-2016$. 
pitted against skeptics. Scattered amidst the polemic rhetoric were some contemplative thinkers. Discourse analysis identified nine attributes of contemplation significant to digital technology and pedagogy in higher education. Examining the attributes provides a framework for making purposeful decisions about when, which, and to what extent to use digital technology. The most constructively critical articles were those categorized as "Positive and Negative" in Theme 1. Therefore, the hub of the Contemplative Technopedagogy Framework requires an educator to simultaneously consider both the positive and negative aspects of a digital technology. Findings from the research indicate that an adaptable mindset is foundational to engaging in contemplative technopedagogy. Surrounding the hub are the nine attributes of contemplative technology grouped into five areas of focus: Pedagogy Focused, Learner Focused, Technology Focused, Attention Focused, Context Focused.

\section{Pedagogy Focused}

In many ways, contemporary higher education works from the assumption "that learning remains in a 'centered' activity with large numbers of students routinely focused on the teacher as well as a limited selection of carefully selected repositories of knowledge such as textbooks" (Raschke, 2003, p. 4). The Pedagogy Focused area of the Contemplative Technopedagogy Framework emphasizes that a pedagogy should guide digital technology decisions, not vice versa. Moreover, this area calls for the reorientation of institutional faculty development initiatives to focus on pedagogy first and then digital technology.

\section{Learner Focused}

Digital technology should foster connections and not create distractions within the teaching-learning environment. Digital technology has the power to connect. It has "expanded the ability of average citizens to express our ideas, circulate them before a larger public, and pool information in the hopes of transforming society," (Jenkins, 2008, p. 273) thereby facilitating opportunities for a widespread and bottom-up participatory culture. Within a participatory educational culture each learner "builds a trail of his interest through the maze of materials available to him" (Bush, 1945). Gender specificity aside, this is a remarkable description of how we might recast higher education with a contemplative technopedagogy. Digital technology has the power to distract. McLuhan (1960) wondered, "With learning and teaching becoming the business of everybody, round-the-clock, and round-the-globe, what becomes of the older roles and relations of teacher and student?" In the contemporary higher education ecosystem, it is important to cultivate a technopedagogy that encourages all participants in the teaching-learning environment to connect with each other and also practice mindfulness use of digital technology. In this environment, teachers and students engage and disengage with technology when appropriate.

\section{Technology Focused}

The Contemplative Technopedagogy Framework requires a commitment from the educator to be both learner and teacher. Digital technology is constantly evolving. So too should an educator's knowledge of that digital technology and the ways it might or might not be applied to the teaching-learning environment. If a digital technology is new to the teacher, it may or may not be new to the learner. Teachers should show learners what they already know, share perspectives on the pros and cons, and ask learners how they might (or already do) use the digital technology. Teaching is not about "telling students answers," (Postman and Weingartner, 1969, p. 194) but about working with learners "to find and address problems that are real and significant to them" (Wesch, 2013, p. 73). Moreover, the Technology Focused area requires teachers to examine how a specific digital technology did or did not work well during a particular course. Building, changing, tweaking, or removing an assignment is necessary in response to evaluating a specific technology's value to the teaching-learning environment.

\section{Attention Focused}

Digital technology can engage and enrich, but also distract. The Attention Focused area calls for educators to focus less on the polemic rhetorics of disruption and revolution and turn attention to matters of intentionality. Gazzaley and Rosen (2016, p. 181) suggest that "there are two approaches by which we can diminish the negative impact of interference on our lives: changing our brains and changing our behavior." Being present requires us to calm our frantic thoughts and change the way our brains operate through contemplation, practicing mindfulness, and being thoughtful about which, when, why, how, and to what extent to integrate digital technology into the teaching-learning environment. Changing our behavior requires $u s$ to think and act intentionally with regard to digital technology and pedagogy.

\section{Context Focused}

Digital technology features prominently in the higher education ecosystem. Learners come into higher education with a lifetime of experience with digital technology and are perceived as comfortable with the ubiquity of digital technology. The kinds of assumptions teachers make about digital technologies and about learners drastically influence the teaching-learning environment. It is important to probe assumptions and understand preconceived notions about human and technological actors. An unexamined embrace or discarding of digital technology is a surefire recipe for disaster, or at least dissatisfaction. Following suit, when formulating a Contemplative Technopedagogy Framework it is not enough to simply acknowledge the presence of technology in higher education. "Technologies live in complex ecologies. The meaning of anyone depends on what others are available" (Turkle, 2011, p. 188). It is necessary to carefully examine the whys, hows, and consequences of technopedagogical decisions within the larger sociocultural context.

\section{CONCLUSION}

This research identified that contemplation is largely absent from discourse about pedagogy and digital technology in United States higher education as represented within The Chronicle of Higher Education. This discourse not only captures 
individual sentiments, but is indicative of institutional ideologies regarding digital technology and teaching. When contemplation is absent, it becomes far easier to make uncritical decisions about pedagogy with technology. When contemplation is a key component of the decision-making process, it is far easier to ponder when, which, to what extent, how, with whom, and for what purpose to integrate digital technology into the teachinglearning environment. A framework is needed to encourage stakeholders at all levels of higher education (e.g., educators, institutes, universities) to make purposeful and engaged decisions about integrating digital technology into teaching-learning environments. The Contemplative Technopedagogy Framework introduced in this manuscript is a step in that direction.

It's about promise, but also about problems. The either/or binary is outmoded. It is not a matter of entirely dismissing digital technology or wholeheartedly embracing digital technology. Higher education requires a dynamic both/and approach. We must acknowledge and address the pros and cons of digital technology in tandem. Digital technology holds great promise as catalyst for learning. However, a pedagogical shift is required to realize this potential. As this close analysis of $\mathrm{CHE}$ indicates, it is not only about new technology or new curricula, but the need for a cultural shift with regard to how we see technology and pedagogy in higher education. Digital technology can be an asset for teaching and learning if it is adopted with a contemplative technopedagogy.

Acknowledging the complex interrelations among digital technology and pedagogy the Contemplative Technopedagogy Framework holds promise for higher education's two most

\section{REFERENCES}

About The Chronicle of Higher Education (2017). Available online at: http://www.chronicle.com/page/the-chronicle-of-higher/609 (accessed February 4, 2017)

Anderson, T., and Dron, J. (2011). Three generations of distance education pedagogy. Int. Rev. Res. Open Distrib. Learn. 12, 80-97. doi: 10.19173/irrodl. v12i3.890

Bijker, W. E., Hughes, T. P., and Pinch, T. (eds). (2012). The Social Construction of Technological Systems: New Directions in the Sociology and History of Technology (Anniversary). Cambridge, MA: MIT Press.

Blin, F., and Munro, M. (2008). Why hasn't technology disrupted academics' teaching practices? Understanding resistance to change through the lens of activity theory. Comput. Educ. 50, 475-490. doi: 10.1016/j.compedu.2007.09.017

Boisselle, J. H., Fliss, S., Mestre, L. S., and Zinn, F. (2004). Talking toward technopedagogy. Resour. Shar. Inf. Netw. 17, 123-136. doi: 10.1300/j121v17n01_10

Booth, A., Papaioannou, D., and Sutton, A. (2012). Systematic Approaches to a Successful Literature Review, 1 Edn. Thousand Oaks, CA: SAGE Publications Ltd.

Brooks, D. C. (2016). ECAR Study of Undergraduate Students and Information Technology, 2016. Louisville, CO: ECAR.

Browne, T., Jenkins, M., and Walker, R. (2006). A longitudinal perspective regarding the use of VLEs by higher education institutions in the United Kingdom. Interact. Learn. Environ. 14, 177-192. doi: 10.1080/ 10494820600852795

Buchmann, M. (1989). The careful vision: how practical is contemplation in teaching? Am. J. Educ. 98, 35-61. doi: 10.1086/443943

Buck, G. H. (1989). Teaching machines and teaching aids in the ancient world. McGill J. Educ. 24, 31-54.

Burgess, M. L., Slate, J. R., Rojas-LeBouef, A., and LaPrairie, K. (2010). Teaching and learning in second life: using the community of inquiry (CoI) model to relevant social groups - learners and teachers. Both groups can utilize this framework to foster a more transformative educational environment. Not a prescriptive approach to higher education, this is an outline of a normative vision to guide pedagogical engagement with technology. Rethinking the purpose and practice of digital technology in higher education will (and rightly must) call into question sociocultural conceptions of education, learning, knowledge, teaching, and pedagogy. Quite simply, contemplation can bring a higher quality to technopedagogy. The Contemplative Technopedagogy Framework asks scholars and practitioners to thoughtfully engage in technopedagogical decisions at all scales or any site within contemporary higher education. Such a contemplative approach to matters of teaching with digital technology is a step toward realizing more reflexive and purposeful higher education teaching-learning environments.

\section{DATA AVAILABILITY STATEMENT}

The raw data supporting the conclusions of this article will be made available by the authors, without undue reservation.

\section{AUTHOR CONTRIBUTIONS}

JS was the sole author of this manuscript; conceived of and designed research; collected, analyzed, and interpreted data; and composed the manuscript.

support online instruction with graduate students in instructional technology. Internet High. Educ. 13, 84-88. doi: 10.1016/j.iheduc.2009.12.003

Burggraf, S., and Grossenbacher, P. (2007). Contemplative modes of inquiry in liberal arts education. LiberalArtsOnline 7, 1-9.

Bush, V. (1945). As We May Think. Washington, DC: The Atlantic.

Campbell, G. (2006). Education information technologies and the augmentation of human intellect. Change 38, 26-31. doi: 10.3200/chng.38.5.26-31

Coeckelbergh, M. (2017). Using Words and Things: Language and Philosophy of Technology. Abingdon: Taylor \& Francis.

Cook-Sather, A. (2001). Unrolling roles in techno-pedagogy: toward new forms of collaboration in traditional college settings. Innov. High. Educ. 26, 121-139.

Engelbart, D. (1962). Augmenting Human Intellect: A Conceptual Framework (Summary Report No. AFOSR-3223). Palo Alto, CA: Stanford Research Institute.

Farman, J. (2012). Encouraging Distraction? Classroom Experiments with Mobile Media. Available online at: http://www.chronicle.com/blogs/profhacker/ encouraging-distraction-classroom-experiments- with-mobile-media/38454 (accessed August 17, 2017).

Felt, U., Fouché, R., Miller, C. A., and Smith-Doerr, L. (eds). (2016). The Handbook of Science and Technology Studies, 4th Edn. Cambridge, MA: MIT Press.

Fisher, K. M. (2017). Look before you leap: reconsidering contemplative pedagogy. Teach. Theol. Religion 20, 4-21. doi: 10.1111/teth.12361

Foucault, M. (2002). The Archaeology of Knowledge, 2 Edn. New York, NY: Routledge.

Gazzaley, A., and Rosen, L. D. (2016). The Distracted Mind: Ancient Brains in a High-Tech World. Cambridge, MA: The MIT Press.

Gose, B. (2010). Learning the Art of Virtual Instruction. Washington, DC: The Chronicle of Higher Education.

Green, K. C., and Gilbert, S. W. (1995). Great expectations: content, communications, productivity, and the role of information technology in higher education. Change 27, 8-18. doi: 10.1080/00091383.1995.9937733

Guest, G., MacQueen, K. M., and Namey, E. E. (2012). Applied Thematic Analysis. Thousand Oaks, CA: SAGE Publications. 
Gunnlaugson, O., Sarath, E. W., Scott, C., and Bai, H. (2014). Contemplative Learning and Inquiry Across Disciplines. Albany, NY: SUNY Press.

Hargittai, E. (2010). Digital Na(t)ives? Variation in internet skills and uses among members of the "Net Generation". Sociol. Inq. 80, 92-113. doi: 10.1111/j.1475682X.2009.00317.x

Harrington, C. F., Gordon, S. A., and Schibik, T. J. (2004). Course management system utilization and implications for practice: a national survey of department chairpersons. Online J. Distance Learn. Adm. 7. Available online at: http://www. westga.edu/ distance/ojdla/winter74/harrington74.htm

Hart, T. (2004). Opening the contemplative mind in the classroom. J. Transformat. Educ. 2, 28-46. doi: 10.1177/1541344603259311

Hawkins, B., and Rudy, J. (2007). EDUCAUSE Core Data Service: Fiscal Year 2006 Summary Report. Washington, DC: EDUCAUSE.

Hughes, T. P. (2005). Human-Built World: How to Think about Technology and Culture, 2nd Edn. Chicago, IL: University of Chicago Press.

Jenkins, H. (2008). Convergence Culture: Where Old and New Media Collide (Revised Edition). New York, NY: NYU Press.

Kidwell, P. A., Ackerberg-Hastings, A., and Roberts, D. L. (2008). Tools of American Mathematics Teaching, 1800-2000. Baltimore, MD: Johns Hopkins University Press.

Kline, R. R. (2006). Cybernetics, management science, and technology policy: the emergence of "information technology" as a keyword, 1948-1985. Technol. Cult. 47, 513-535. doi: 10.1353/tech.2006.0184

Koehler, M. J., Mishra, P., and Cain, W. (2013). What is technological pedagogical content knowledge (TPACK)? J. Educ. 193, 13-19.

Krippendorf, K. (2012). Content Analysis, an Introduction to Its Methodology, 3rd Edn. Thousand Oaks, CA: Sage Publications.

Lasswell, H. D., Lerner, D., Pool, I., and de, S. (1952). The Comparative Study of Symbols. Stanford, CA: Stanford University Press.

Levy, D. M. (2006). More, faster, better: governance in an age of overload, busyness, and speed. First Monday doi: 10.5210/fm.v0i0.1618

Levy, D. M. (2007). No time to think: reflections on information technology and contemplative scholarship. Ethics Inf. Technol. 9, 237-249. doi: 10.1007/ s10676-007-9142-6

Lusted, D. (1986). Why pedagogy? Screen 27, 2-16. doi: 10.1093/screen/27.5.2

Maloney, E. J. (2007). What Web 2.0 Can Teach us about Learning. Washington, DC: The Chronicle of Higher Education.

Mandell, H. (2015). No Phones, Please, this is a Communications Class. Washington, DC: The Chronicle of Higher Education.

Marx, L. (1997). "Technology": the emergence of a hazardous concept. Soc. Res. 64, 965-988.

McLuhan, M. (1960). Report on Project in Understanding New Media. Washington, DC: The National Association of Educational Broadcasters.

McLuhan, M. (1964). Understanding Media: The Extensions of Man. New York, NY: New American Library.

Miller, J. (2017). From EDUPUNK to open policy: critical technology praxis within higher education. Prof. Geogr. 70, 165-173. doi: 10.1080/00330124.2017. 1326086

Morgan, P. F. (2015). A brief history of the current reemergence of contemplative education. J. Transformat. Educ. 13, 197-218. doi: 10.1177/15413446145 64875

Neuendorf, K. A. (2016). The Content Analysis Guidebook, 2nd Edn. Los Angeles, CA: SAGE Publications, Inc.

Newson, J. (1999). Techno-pedagogy and disappear in context. Academe 85, 52-55. doi: $10.2307 / 40251770$

Office of Educational Technology (2017). Reimagining the Role of Technology in Higher Education: Higher Education Supplement to the National Education Technology Plan. Available online at: https://tech.ed.gov/higherednetp/ (accessed August 21, 2017).

Oldenziel, R. (2006). Introduction: signifying semantics for a history of technology. Technol. Cult. 47, 477-485. doi: 10.1353/tech.2006.0194

Parry, M. (2013). You're Distracted. This Professor Can Help. Washington, DC: The Chronicle of Higher Education.

Postman, N., and Weingartner, C. (1969). Teaching as a Subversive Activity. New York, NY: Dell Publishing Co.

Privateer, P. M. (1999). Academic technology and the future of higher education: strategic paths taken and not taken. J. High. Educ. 70, 60-79. doi: 10.2307/ 2649118
Pyenson, L. (2011). Technology's Triumph over Science. Washington, DC: The Chronicle of Higher Education.

Raschke, C. (2003). The Digital Revolution and the Coming of the Postmodern University. London: Routledge.

Reeves, T. C., Herrington, J., and Oliver, R. (2005). Design research: a socially responsible approach to instructional technology research in higher education. J. Comput. High. Educ. 16:96. doi: 10.1007/bf02961476

Saltzer, A. (2011). Lessons Learned in Playful Game Design. Available online at: http://www.chronicle.com/blogs/profhacker/lessons-learned-in-playfulgame-design/33876 (accessed August 17, 2017).

Sample, M. (2011). Teaching Extra-Large Classes and the Role of Technology. Available online at: http://www.chronicle.com/blogs/profhacker/teachingextra-large-classes-and-the-role-of-technology/30046 (accessed August 17, 2017).

Schatzberg, E. (2006). Technik comes to America: changing meanings of technology before 1930. Technol. Cult. 47, 486-512. doi: 10.1353/tech.2006. 0201

Shapiro, S. L., Brown, K. W., and Astin, J. A. (2008). Toward the Integration of Meditation into Higher Education: A Review of Research. Florence: The Center for Contemplative Mind in Society.

Sismondo, S. (2007). "Science and technology studies and an engaged program," in The Handbook of Science and Technology Studies, 3rd Edn, eds E. J. Hackett, O. Amsterdamska, M. E. Lynch, J. Wajcman, and W. Bijker (Cambridge, MA: MIT Press), 13-32.

Stock, B. (2006). The contemplative life and the teaching of the humanities. Teach. Coll. Rec. 108, 1760-1764. doi: 10.1111/j.1467-9620.2006.00759.x

Turkle, S. (2004). How computers change the way we think. Chron. High. Educ. 50:B26.

Turkle, S. (2011). Alone Together: Why We Expect More from Technology and Less from Each Other. New York, NY: Basic Books.

Varlotta, L. (2017). Mobile technology meets mindful technology. Educause Rev. 8-9. doi: 10.1049/et.2016.0303

Weber, R. P. (1990). Basic Content Analysis, 2nd Edn. Thousand Oaks, CA: Sage Publications.

Wesch, M. (2013). "From knowledgable to knowledge-able: learning in new media environments," in Hacking the Academy: New Approaches to Scholarship and Teaching from Digital Humanities, eds D. Cohen and T. Scheinfeldt (Ann Arbor, MI: The University of Michigan Press), 69-77. doi: 10.2307/j.ctv65sw j3.18

Williams, R. (1985). Keywords: A Vocabulary of Culture and Society (Revised). Oxford: Oxford University Press.

Williams, R. (2002). Retooling: A Historian Confronts Technological Change. Cambridge, MA: MIT Press.doi: 10.7551/mitpress/5935.001.0001

Winner, L. (1977). Autonomous Technology: Technics-Out-of-Control as a Theme in Political Thought. Cambridge, MA: MIT Press.

Woolgar, S. (1986). On the alleged distinction between discourse and praxis. Soc. Stud. Sci. 16, 309-317. doi: 10.1177/0306312786016002006

Wymer, K. (2006). The Professor as Instant Messenger. Washington, DC: The Chronicle of Higher Education.

Young, J. R. (1998). Corporate Partnerships Help 2 Colleges Offer Laptops for All. Washington, DC: The Chronicle of Higher Education.

Young, J. R. (2012). A Tech-Happy Professor Reboots After Hearing His Teaching Advice Isn't Working. Washington, DC: The Chronicle of Higher Education.

Zajonc, A. (2006). Contemplative and transformative pedagogy. Kosm. J. V, 1-3.

Zajonc, A. (2013). Contemplative pedagogy: a quiet revolution in higher education. New Dir. Teach. Learn. 2013, 83-94. doi: 10.1002/tl.20057

Conflict of Interest: The author declares that the research was conducted in the absence of any commercial or financial relationships that could be construed as a potential conflict of interest.

Copyright (c) 2020 Shanks. This is an open-access article distributed under the terms of the Creative Commons Attribution License (CC BY). The use, distribution or reproduction in other forums is permitted, provided the original author(s) and the copyright owner(s) are credited and that the original publication in this journal is cited, in accordance with accepted academic practice. No use, distribution or reproduction is permitted which does not comply with these terms. 